\title{
Prevalence of Hepatitis C Virus (HCV) and Human Immunodeficiency Virus (HIV) Co-Infection Among Pregnant Women Attending Antenatal Clinics in Abuja, Nigeria
}

\author{
Ya'aba $\mathrm{Y}^{1}$, Isu $\mathrm{NR}^{2}$, Mohammed SB ${ }^{1}$, Oladepo $\mathrm{DK}^{1}$, Ibrahim $\mathrm{K}^{1}$, \\ Oladusu $\mathrm{P}^{1}$, Izebe $\mathrm{KS}^{1}$ and Onoja $\mathrm{AJ}^{3}$ \\ ${ }^{I}$ Department of Microbiology and Biotechnology \\ National Institute for Pharmaceutical Research and Development (NIPRD) Idu-Abuja, Nigeria \\ ${ }^{2}$ Department of Biological Sciences, University of Abuja, Abuja, Nigeria \\ ${ }^{3}$ African Health Project, Abuja, Nigeria
}

\begin{abstract}
Co-infection with Hepatitis C Virus (HCV) is rare in people living with Human Immunodeficiency Virus (HIV) but where it occurs, it causes treatment dilemma. Many people with HIV are unaware that they may also be infected with HCV; but due to shared routes of transmission it happens. Coinfection with this virus complicates issues related to diagnosis, clinical disease progression, monitoring disease activity, treatment options and basic immunology. In view of the above and recent massive antiretroviral therapy program in Nigeria, it has become necessary to address issues of potential impact of co-infection (HCV/HIV) as it affects clinical care of ante-natal women in Abuja, Nigeria. Blood samples from one thousand two hundred $(1,200)$ ante-natal women collected from January 2005 to May 2006 were tested for antibodies against HIV- 1 and HIV-2 using a rapid test kit Unigold and Genie $11 \mathrm{HIV}-1 / \mathrm{HIV}-2$. These samples were also tested for antibodies against HCV by rapid chromatographic immunoassay $\mathrm{HCV}$ kit. The positive samples to $\mathrm{HCV}$ antibodies were further subjected to western blot for confirmation. Two hundred and three (203) samples were confirmed positive for HIV antibodies representing $16.9 \%$. Five (5) samples out of 203 HIV positive samples were positive for HCV antibodies, representing $2.5 \%$. The results show that, $2.5 \%$ of HIV seropositive women may present with HCV co-infection because the route of transmission for both viruses have shown to be similar. There is therefore the need to fully integrate HCV screening as a routine test in the antenatal clinics.
\end{abstract}

Keywords: HIV; HCV; HIV/HCV co-infection; pregnant; antenatal care

\section{Introduction}

Hepatitis $\mathrm{C}$ virus (HCV) is a parenterally transmitted hepatotrophic virus that persists in the majority of those infected. Chronic infection with HCV may result in cirrhosis leading to end-stage liver disease and hepatocellular carcinoma many years after the initial infection [13].

Many patients infected with human immunodeficiency virus (HIV) are also co-infected with hepatitis $\mathrm{C}$ virus (HCV) due to shared modes of transmission through transfusion of blood products and intravenous drug use (IVDU). The prevalence of HIV/HCV co-infection ranges from 4 to $90 \%$ depending on the percentage of IVDUs in the population [6]. Central Africa is considered to be an area of high endemic HCV, with anti-HCV antibodies in 5-15\% [8]. HCV has reached epidemic proportion world wide. More than one million new cases of infection are reported annually and it is believed to be more prevalent than hepatitis B virus (HBV) infection [5].

* Corresponding Author: Email: yakyabnig@yahoo.com 
A review by Madhava et al., (2002) reported that the estimated prevalence of $\mathrm{HCV}$ infection in Nigeria was $2.1 \%$ in general population; $3.6 \%$ in blood donors, and $5.1 \%$ in high-risk populations (those with liver disease or multiple exposures to blood and blood products).

Although, HCV has been reported in Nigeria by a number of scientists $[1,9$,$] no data or information$ on the prevalence of HIV/HCV co-infection among antenatal women in Abuja, Nigeria. Barett and Grants, (2002) reported that co-infection of HIV/HCV has complicated issues relating to diagnosis, clinical disease progression, monitoring disease activity, treatment options and basic immunology. This study is designed to identify the prevalent rate of $\mathrm{HIV} / \mathrm{HCV}$ co-infection in pregnant women attending antenatal in some selected public hospital in Abuja for better health care delivery.

\section{Methods}

The study was conducted on one thousand two hundred $(1,200)$ pregnant women attending antenatal care from January 2005 through May 2006 in government approved hospitals in Abuja, Nigeria. The subjects were voluntarily counseled for the viruses and consent obtained. Five millilitres of blood were carefully drawn from the veins of the subjects into a well labeled EDTA blood sample container for plasma samples according to the standard protocol. The blood samples were centrifuged at 4,452 $\mathrm{g}$ for $10 \mathrm{minutes}$ and about $2 \mathrm{ml}$ of plasma recovered were aliquoted into well-labeled $2 \mathrm{ml}$ cryovials. The tests were carried out immediately at National Institute for Pharmaceutical Research and Development (NIPRD), Idu, Abuja.

HIV screening was done using a rapid test kit, Uni-Gold HIV kit (Trinity Biotech, Bray, Ireland) and further screened HIV antibodies using Genie 11 HIV-1/HIV-2 (Bio-Rad, 3 Boulevard Raymond Poincare 92430 Marnes LA Coquette- France). Those samples tested positive for HIV antibodies were tested for antibodies against HCV using rapid chromatographic immuno-assay HCV kit ACON (Acon Laboratories Inc). The positive HCV antibodies were further confirmed using Western blot (Trinity Biotech, Bray, Ireland) according to manufacturer's specifications.

\section{Results}

The mean age of the one thousand two hundred $(1,200)$ pregnant women that participated in this study was 27.5 years (range 15-40 years). Seventy five per cent of the pregnant women were between 15-30 years and twenty five per cent were older than 30 years.

The one thousand two hundred $(1,200)$ subjects screened for HIV antibodies, 203 samples were positive for HIV antibodies representing $16.9 \%$. Five (5) of the samples were positive for HCV antibodies representing $2.46 \%$ of the total pregnant women population infected with HIV in the study (Fig 1).

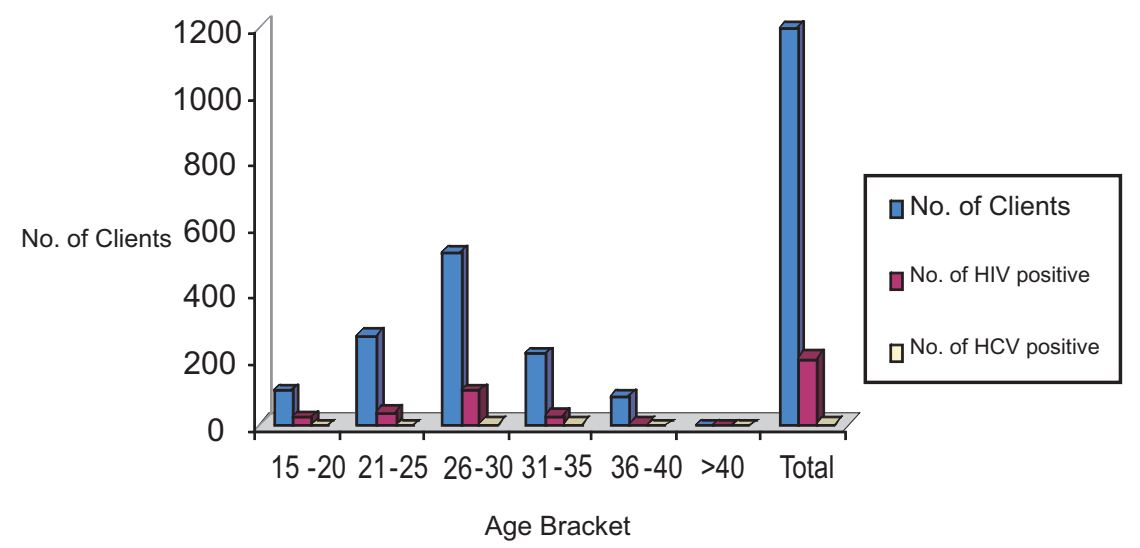

Figure 1: Prevalence of HCV among pregnant women living with HIV infections attending antenatal clinics in Abuja 


\section{Discussion and Conclusion}

Estimating the long-term effects of HIV and HCV co-infection can only be done with certainty when the epidemiology of the disease is known. Although some studies show the economic cost of HIV infection in sub-Saharan Africa to be colossal $[3,4$,$] such data do not exist on HIV and HCV co-$ infection.

A press release by WHO/AFRO in 2001 indicates that over $75 \%$ of blood units transfused in Africa are not tested for HIV antibodies, while more than $80 \%$ of the countries in the region do not test blood units for HCV before transfusion. Diagnosis of HIV and HCV co-infection in the region is still handicapped by several factors in the region. These include: ignorance, self-medication, cultural beliefs and traditional practices, finance, manpower, equipment and supplies.

The study was conducted with multiple rapid test kits in the screening of HIV antibodies as recommended by WHO using two different testing strategies (algorithms) involving ELISA and/ or simple or rapid assays for surveillance [11].

The observed prevalence of HCV infection among HIV infected pregnant women in Abuja were somewhat lower $(0.58 \%)$ than the $5.1 \%$ reported by Madhava et al., (2002) for the high risk population in Nigeria. This low prevalence could be due to socio-economic difference in the study population or geographical area or could indicate a general decrease in the prevalence of HCV infection.

This result strongly indicates a need for HCV screening in blood transfusion centres, routine antenatal care, HIV diagnosis and treatment centres. This is because patients who are co-infected with HIV and HCV are at increased risk of disease progression as reported by Sanchez Quijan et al., (1995).

\section{Recommendations}

1. Campaign need be intensified on the implication of HCV infection either alone or with HIV since they both share the same mode of transmission.

2. HCV screening should be included as part of routine test for diagnosis and treatment of HIV in the health facilities in Nigeria.

3. Protocols for HCV counseling and testing in the health facilities should be developed.

\section{Acknowledgment}

We want to thank the National Institute for Pharmaceutical and Development (NIPRD) for their support.

\section{References}

1. Adewuyi J. O. (1996): Prevalence of antibodies to hepatitis C virus among normal blood donors and multi-transfused sickle-cell anemia patients in Nigeria. Trop. Doct. 26(1): 29-30

2. Barrett $L$ and Grants $M$ (2002): Brothers in harm: immunological and clinical implications of co infection with hepatitis $\mathrm{C}$ virus and human immunodeficiency virus. Clinical and Applied Immunological Reviews 2: 93-114

3. Bloom DE and Glied S (1991): Benefits and costs of HIV testing. Science 252 (5014):1798804.

4. Cohen D. (1992): The economic impact of the HIV epidemic. Issues Paper No 2.UNDP.

5. Coleman PJ, Mc Quillan GM, Moyer LA, Lambert SB and Morgolis HS (1999): Incidence of Hepatitis B virus infection in the United States, 1976-1994, estimates from National Health and Nutrition examination survey. J Infect Dis 178:954-959.

6. Dieterich DT, Purow JM and Rajapaksa R (1999): Activity of combination therapy with interferon alfa-2b plus ribavirin in chronic hepatitis C patiente coinfected with HIV. Semin. Liver Dis. 19 (suppl. 1):87-94. 
7. Madhava V, Burgess C, and Drucker E. (2002): Epidemiology of chronic Hepatitis C virus infection in sub-Saharan Africa. Lancet Infect Dis. 2:293-302

8. Ndjomou J, Kupfer B, Kochan B, Zekeng L, Kaptue L, and Matz B (2002): Hepatitis C virus infection and genotypes among human immunodeficiency virus high- risk groups in Cameroon. JMed Virol 66:179-186.

9. Ojo OS, Thursz M, Thomas HC, Ndububa DA, Adeodu OO, Rotimi O, Lawal AA, Durcosinmi MA, Akonai AK, and Fatusi AO (1998): Hepatitis B virus markers, hepatitis D virus antigen and Hepatitis $\mathrm{C}$ virus antibodies in Nigerian patients with chronic liver disease. East Afr. Med J. 72(11): 719-21

10. Sanchez-Quijano A, Andrew J. and Gavilian F. (1995): Influence of human immunodeficiency virus (HIV) infection on the natural course of chronic parenterally acquired hepatic C. Eurj Clin Microbiol infect Dis 14:949-53.

11. World Health Organisation (1992): Global programme on AIDS-Recommendations for the selection and use of HIV antibody tests. Weekly Epidemiol Rec. 20: 145-149.

12. WHO/AFRO (2001): Ensuring blood transfusion safety in Africa. Press Release.

13. Afdhal, N.H (2004): The natural history of hepatitis C, Semin. Liv. Dis. 24 (Suppl. 2), pp. 3-8. 